\title{
Ethanol Impairs Post-Prandial Hepatic Protein Metabolism
}

\author{
Pierpaolo De Feo, Elena Volpi, Paola Lucidi, Guido Cruciani, Francesca Monacchia, Gianpaolo Reboldi, \\ Fausto Santeusanio, Geremia B. Bolli, and Paolo Brunetti \\ Department of Internal Medicine, Endocrine and Metabolic Sciences, University of Perugia, 06126 Perugia, Italy
}

\begin{abstract}
The effects of acute ethanol ingestion on whole body and hepatic protein metabolism in humans are not known. To simulate social drinking, we compared the effects of the association of a mixed meal $(632 \mathrm{kcal}, 17 \%$ amino acids, $50 \%$ glucose, $33 \%$ lipids) with a bottle of either table wine (ethanol content $71 \mathrm{~g}$ ) or water on the estimates $\left(\left[1-{ }^{14} \mathrm{C}\right]-\right.$ leucine infusion) of whole body protein breakdown, oxidation, and synthesis, and on the intravascular fractional secretory rates (FSR) of hepatically (albumin, fibrinogen) and extrahepatically (IgG) synthesized plasma proteins in two randomized groups (ethanol $n=7$, water $n=7$ ) of healthy nonalcoholic volunteers. Each study was carried out for 8 h. Protein kinetics were measured in the overnight post-absorptive state, over the first $4 \mathrm{~h}$, and during a meal infusion (via a nasogastric feeding tube at constant rate) combined with the oral ingestion of wine or water, over the last $4 \mathrm{~h}$. When compared with water, wine ingestion during the meal reduced $(P<0.03)$ by $24 \%$ the rate of leucine oxidation, did not modify the estimates of whole body protein breakdown and synthesis, reduced $(P<0.01)$ by $\sim 30 \%$ the FSR of albumin and fibrinogen, but did not affect IgG FSR. In conclusion, $70 \mathrm{~g}$ of ethanol, an amount usual among social drinkers, impairs hepatic protein metabolism. The habitual consumption of such amounts by reducing the synthesis and/or secretion of hepatic proteins might lead to the progressive development of liver injury and to hypoalbuminemia also in the absence of protein malnutrition. (J. Clin. Invest. 1995. 95:1472-1479.) Key words: alcohol • leucine metabolism • albumin • fibrinogen • immunoglobulins
\end{abstract}

\section{Introduction}

Despite the common presence of alcohol in the diet of western countries (1), very few data are available on the potential interactions between acute or short-term ethanol ingestion and protein metabolism in humans. Acute ethanol administration inhibits protein synthesis in vitro in isolated hepatocytes (2), in perfused livers (3), and in vivo in rat liver (4). In humans it is known that the intravenous infusion of ethanol reduces urinary nitrogen excretion (5); whereas the isocaloric replacement of

Address correspondence to Dr. Pierpaolo De Feo, IMISEM, Via E. dal Pozzo, 06126 Perugia, Italy. Phone: 75-5783632; FAX: 75-5730855.

Received for publication 9 September 1994 and in revised form 18 November 1994.

J. Clin. Invest.

(C) The American Society for Clinical Investigation, Inc.

0021-9738/95/04/1472/08 \$2.00

Volume 95, April 1995, 1472-1479 glucose and lipids with ethanol in a 3-6-wk diet of normal (6) or alcoholic subjects $(7,8)$ results in a negative nitrogen balance and weight loss. The presence of adequate amounts of amino acids in the diet of these subjects $(6,8)$ rules out the possibility that protein malnutrition, commonly indicated as the cause of many complications of chronic alcoholism (9), was responsible for the negative nitrogen balance. Thus a direct "toxic" effect of ethanol ingestion on protein metabolism must be considered. However, nitrogen balance studies (6-8) cannot provide any insight into the mechanism(s), i.e., increased protein breakdown and/or decreased protein synthesis, by which ethanol leads to net protein catabolism.

The aim of this study was to establish the effects of acute ethanol ingestion on the rates of whole body protein breakdown, synthesis, and oxidation in the absorptive state. Additionally, since ethanol is almost exclusively metabolized by the liver (10), the effects on the secretion rates of the two most represented plasma proteins synthesized by the liver (albumin and fibrinogen) were determined and compared with those of the extrahepatically synthesized immunoglobulin $\mathrm{G}(\mathrm{IgG})$. To simulate a common situation of social drinking, i.e., alcohol with a meal, the effects of the ingestion of a bottle of table wine ( 71 $\mathrm{g}$ of ethanol over $3 \mathrm{~h}$ ) were compared with those of mineral water during the intragastric infusion of a mixed meal in two randomized groups of healthy volunteers.

\section{Methods}

Materials. Purity, sterility, and radio purity of $\mathrm{L}-\left[1-{ }^{14} \mathrm{C}\right]$ leucine (sp act $57 \mathrm{mCi} / \mathrm{mmol}$; Amersham International, Buckinghamshire, United Kingdom) were determined before use (11).

Protocol. After receiving Institutional Review Board approval, informed consent was obtained from 14 healthy volunteers ( 2 females, 12 males), with normal physical examination, routine blood analysis, and without any serological evidence of viral hepatitis. All of them reported to be occasional consumers of moderate amounts of alcoholic beverages, usually $<120 \mathrm{~g} / \mathrm{wk}$. The subjects were randomly divided into a water $(n=7)$ or an ethanol $(n=7)$ group, and matched for sex, age (water $23 \pm 1$, ethanol $24 \pm 1 \mathrm{yr}$ ), weight (water $67 \pm 1$, ethanol $68 \pm 4$ $\mathrm{kg}$ ), and body mass index (water $22.0 \pm 0.4$, ethanol $22.1 \pm 0.7 \mathrm{~kg} / \mathrm{m}^{2}$ ). All subjects were studied $3 \mathrm{~d}$ after consuming a weight-maintenance diet of $35 \mathrm{kcal} \cdot \mathrm{kg}^{-1} \cdot \mathrm{d}^{-1}$ containing 55,30 , and $15 \%$ carbohydrate, fat, and protein, respectively, and not drinking alcoholic beverages. After fasting overnight, the volunteers were admitted to the Clinical Research Unit of the Dipartimento di Medicina Interna e Scienze Endocrine e Metaboliche of the University of Perugia, at $\sim 07: 30 \mathrm{~h}$. At $\sim 08: 00 \mathrm{~h}$ an 18-gauge plastic catheter needle was placed in an antecubital vein for the infusion of $\left[1-{ }^{14} \mathrm{C}\right]$ leucine (Harvard syringe pump; Harvard Apparatus, South Natick, MA $)$ and saline $\left(0.5 \mathrm{ml} \cdot \mathrm{min}^{-1}\right.$; Vial Médical, Grenoble, France). A contralateral hand vein was cannulated in a retrograde fashion with a 19-gauge butterfly needle and was maintained at $65^{\circ} \mathrm{C}$ in a thermoregulated Plexiglas box to permit intermittent sampling of arterialized venous blood (12), and a feeding nasogastric tube was inserted for intragastric (ig) ${ }^{1}$ meal infusion (Vial Médical).

1. Abbreviations used in this paper: FSR, fractional secretory rates; ig, intragastric; KIC, $\alpha$-ketoisocaproic acid; SA, specific activity. 
At $\sim$ 09:00 h ( $0 \mathrm{~min})$, a primed-constant intravenous infusion of $\mathrm{L}$ - [1${ }^{14} \mathrm{C}$ ] leucine ( $9 \mu \mathrm{Ci}$ prime, $0.3 \mu \mathrm{Ci} \cdot \mathrm{min}^{-1}$ ) was started and continued for $8 \mathrm{~h}$. At $240 \mathrm{~min}$, after blood and breath sampling, the ig infusion of a liquid mixed meal was started at a rate of $1.75 \mathrm{ml} \cdot \mathrm{min}^{-1}$ and continued until the end of the study ( $480 \mathrm{~min}$ ). The meal provided $17 \%$ of total calories from amino acids, $33 \%$ from lipids, and $50 \%$ from carbohydrates, for a total amount of $632 \mathrm{kcal}$. It was prepared by mixing a complete formula (Isopuramin ${ }^{\circledR}$ Plus $10 \%$; Bieffe Medical, Modena, Italy) of nonessential and essential amino acids (leucine infusion rate $1.25 \pm 0.02$ and $1.27 \pm 0.06 \mu \mathrm{mol} \cdot \mathrm{kg}^{-1} \cdot \mathrm{min}^{-1}$, in the water and ethanol group, respectively) with $84 \mathrm{~g}$ of glucose and a mixed oil solution (Lipofundin ${ }^{\circledR}$ S; B. Braun, Melsungen, Germany). When the ig infusion was started, $150 \mathrm{ml}$ of either mineral water (Nocera Umbra SpA, Caserta, Italy) or table white wine ( $12 \% \mathrm{vol} / \mathrm{vol}$ ethanol content, Rond $\grave{o}^{\otimes}$ Lungarotti, graciously provided by Cantine Lungarotti srl, Torgiano, Italy) was drunk by the volunteers. Then, $50 \mathrm{ml}$ of water or wine was given every $15 \mathrm{~min}$ from 265 to $420 \mathrm{~min}$, for a total amount of $750 \mathrm{ml}$. Since the meal composition of the water and ethanol studies was the same, the two studies differed in energy content by $500 \mathrm{kcal}$, i.e., the amount of calories provided by ethanol $(71 \mathrm{~g}$ of ethanol per $7.1 \mathrm{kcal})$. This variable was preferred to the isocaloric substitution of other fuels with ethanol, because a different supply of glucose and/or lipids could per se affect the rates of leucine kinetics (13), complicating the interpretation of the results.

$8 \mathrm{ml}$ of blood and 2-min breath samples were collected at $-15,0$, $60,120,180,200,220,240,300,360,420,440,460$, and $480 \min$ to measure the plasma concentrations of glucose, insulin, isoleucine, leucine, and $\alpha$-ketoisocaproic acid (KIC), the plasma specific activity (SA) of leucine and $\mathrm{KIC}$, the rates of expired total $\mathrm{CO}_{2}$, total ${ }^{14} \mathrm{CO}_{2}$, and of ${ }^{14} \mathrm{CO}_{2}$ SA. $8 \mathrm{ml}$ of blood was withdrawn at $180,210,240,420,450$, and $480 \mathrm{~min}$ to measure the plasma concentrations and leucine SA of albumin, fibrinogen, IgG, and VLDL-apo-B100. Blood samples $(0.5$ $\mathrm{ml}$ ) to measure plasma ethanol concentrations were collected from 240 to $480 \mathrm{~min}$, every $30 \mathrm{~min}$.

Analytical methods. The plasma concentrations of glucose (Beckman glucose analyzer; Beckman Instruments, Palo Alto, CA), insulin (14), ethanol (Sigma Immunochemicals, St. Louis, MO) (15), albumin (16), fibrinogen (17), and IgG (radial immunodiffusion, Boehringer Mannheim, Mannheim, Germany) (18) were determined as previously described.

The plasma concentrations of isoleucine, leucine, and KIC, the leucine concentration into the infused mixed meal, and the SA of leucine and $\mathrm{KIC}$ were determined by high-performance liquid chromatography (19). Precisely measured volumes of the tracer leucine infusate were mixed with known amounts of unlabeled leucine and analyzed simultaneously by the same means to determine radioactivity and to calculate the infusion rates of the tracers $(20)$.

Expired rates of ${ }^{14} \mathrm{CO}_{2}$ were measured by aspirating 2-min collections of expired air through an ethanolamine solution (20). The SA of breath ${ }^{14} \mathrm{CO}_{2}$ was determined at each breath sampling time by aspirating expired air through hyamine hydroxide (20).

The leucine SA in plasma fibrinogen and albumin was determined as previously described (20). Plasma IgG were purified from $2 \mathrm{ml}$ of serum using protein $\mathrm{A}-$ Sepharose high performance affinity gel, packed in a column C 10/10 (Pharmacia AB, Uppsala, Sweden), that specifically binds the subclasses 1,2 , and 4 of human $\operatorname{IgG}(21)$. Before loading the sample, lipids were removed by hexane extraction (21), and five column volumes of phosphate buffer $0.02 \mathrm{M}$ were used for gel equilibration. After loading the sample, the column was washed with three column volumes of starting buffer, followed by two column volumes of starting buffer plus $0.5 \mathrm{M} \mathrm{NaCl}$ to remove nonspecifically bound proteins. The IgG fraction was eluted with 1.5 column volumes of $0.1 \mathrm{M}$ citric acid, pH 3.3 (22). The purity of the IgG fraction was tested by SDS-PAGE, using standard human IgG (Sigma Immunochemicals). Plasma VLDL-apo-B100 were purified by ultracentrifugation, as previously described (23).

The ${ }^{14} \mathrm{C}$ radioactivity in $\mathrm{KIC}$, leucine, and $\mathrm{CO}_{2}$ was determined with a Tri-Carb 4000 series liquid scintillation system (Packard Instruments,
Downers Grove, IL) with an efficiency $>95 \%$. Each sample corresponding to the leucine peak derived from the hydrolyzed proteins was counted for a period of $40 \mathrm{~min}$ to reduce the coefficient of variation to $<3.5 \%$.

Calculations. Rates of radiolabeled isotope administration were determined multiplying the disintegrations per minute $(\mathrm{dpm})$ per milliliter of infusate by the infusion rate $\left(\mathrm{ml} \cdot \mathrm{min}^{-1}\right)$. Estimates of whole body leucine metabolism were made at near substrate and isotopic steady state between 180-240 min (post-absorptive state) and 420-480 min (absorptive state). The rate of total leucine appearance $\left(\mu \mathrm{mol} \cdot \mathrm{kg}^{-1}\right.$. $\left.\min ^{-1}\right)$ was calculated by dividing the infusion rate of $\left[{ }^{14} \mathrm{C}\right]$ leucine $\left(\mathrm{dpm} \cdot \mathrm{kg}^{-1} \cdot \mathrm{min}^{-1}\right)$ by the plasma $\left[{ }^{14} \mathrm{C}\right] \mathrm{KIC} \mathrm{SA}(\mathrm{dpm} / \mu \mathrm{mol})(11)$. During meal infusion, the rate of endogenous leucine appearance $\left(\mu \mathrm{mol} \cdot \mathrm{kg}^{-1} \cdot \mathrm{min}^{-1}\right)$, an index of whole body proteolysis, was calculated by subtracting the ig leucine infusion rate from the rate of total leucine appearance. This assumes that $(a)$ the ig delivered leucine is completely absorbed and reaches the systemic pool in the form of leucine or KIC (24); and (b) acute ethanol administration does not affect the enteral absorption of amino acids (7). The rate of leucine oxidation $\left(\mu \mathrm{mol} \cdot \mathrm{kg}^{-1} \cdot \mathrm{min}^{-1}\right)$ was calculated by dividing the expired rate of ${ }^{14} \mathrm{CO}_{2}\left(\mathrm{dpm} \cdot \mathrm{kg}^{-1} \cdot \mathrm{min}^{-1}\right)$ by the plasma $\left[{ }^{14} \mathrm{C}\right] \mathrm{KIC} \mathrm{SA}(\mathrm{dpm} / \mu \mathrm{mol})$ (11), and assuming a 70 and an $82 \% \mathrm{CO}_{2}$ recovery in the post-absorptive and in the absorptive state (25), respectively. The rate of nonoxidative leucine disposal $\left(\mu \mathrm{mol} \cdot \mathrm{kg}^{-1} \cdot \mathrm{min}^{-1}\right)$, an estimate of whole body protein synthesis, was calculated by subtracting the rate of leucine oxidation from the total leucine flux. Net leucine balance $\left(\mu \mathrm{mol} \cdot \mathrm{kg}^{-1}\right.$. $\min ^{-1}$ ) was calculated by subtracting the endogenous leucine flux from the nonoxidative leucine disposal. The rate of leucine transmembrane exchange $\left(\mu \mathrm{mol} \cdot \mathrm{kg}^{-1} \cdot \mathrm{min}^{-1}\right)$ between the intra- and the extracellular compartments was calculated by dividing the leucine infusion rate by the difference between plasma leucine and KIC SA (26).

The fractional secretory rates (FSR, percent $\cdot \mathrm{d}^{-1}$ ) of plasma albumin, fibrinogen, and IgG were calculated by dividing the increase (slope) in the SA of leucine derived from hydrolyzed proteins $\left(\mathrm{dpm} \cdot \mathrm{nmol}^{-1} \cdot \mathrm{min}^{-1}\right.$ ) from 180 to $240 \mathrm{~min}$ (post-absorptive state) and from 420 to $480 \mathrm{~min}$ (absorptive state) by the mean plasma KIC SA $(\mathrm{dpm} / \mathrm{nmol})$ over the same time periods and corrected to a daily FSR. The assumptions for the measurement of plasma protein FSR have been recently discussed in detail (27). Experimental evidence suggests that plasma KIC SA closely reflects the precursor pool SA for hepatic protein synthesis in the post-absorptive state (27). To validate the use of plasma KIC SA also during the absorptive period and ethanol ingestion, we determined in three subjects of both groups the SA of leucine derived from the hydrolysis of the apolipoprotein VLDL-apo-B100. This protein was used as a noninvasive method to measure the intrahepatic leucine SA for the following reasons: $(a)$ apo-B100 is almost exclusively synthesized by the liver and secreted as VLDL $(28) ;(b)$ the time required to completely change the plasma protein pool is relatively short $(\sim 5$ h) $(29,30)$; (c) once the whole plasma pool has been replaced, the SA of leucine bound to the apolipoprotein reaches a plateau value that equals the SA of its leucyl-tRNA $(29,30)$; and $(d)$ after secretion the VLDL are continuously converted to LDL (28), thus the SA of leucine-VLDL-apo-B100 represents a sensitive monitor of the changes in the intrahepatic SA of its tRNA (see Results and Fig. 4 for the decline in SA occurring during meal administration). IgG FSR was estimated using either the plasma leucine or KIC SA.

Statistics. Statistical analysis was performed by SAS/STAT software rel. 6.08 (SAS Institute, Cary, NC). The effect of treatment on response variables in the postabsorptive and absorptive state was analyzed using ANOVA for repeated measures (31). Data are expressed as mean $\pm \mathrm{SE}$. Linearity of label incorporation into plasma proteins was tested according to the method suggested by Snedecor and Cochran (32).

\section{Results}

Plasma concentrations of ethanol, glucose, and insulin. The plasma ethanol concentrations were undetectable in the water 


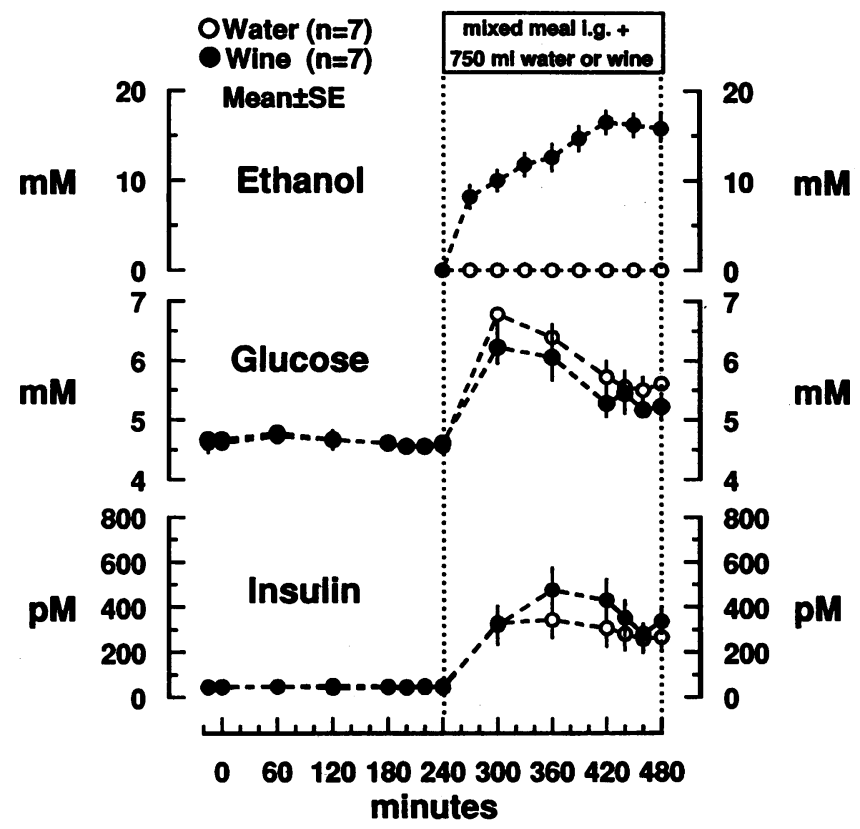

Figure 1. Plasma ethanol, glucose, and insulin concentrations in two groups of healthy volunteers during the post-absorptive (0-240 $\mathrm{min}$ ) and absorptive (240-480 $\mathrm{min}$ ) periods. The mixed glucose-lipid-amino acid meal was given through a nasogastric feeding tube and associated with the ingestion of either $750 \mathrm{ml}$ of table wine $(12 \% \mathrm{vol} / \mathrm{vol}$ ethanol, filled circles) or water (empty circles). The plasma glucose and insulin concentrations did not differ between the two groups.

group. Plasma ethanol concentrations in the ethanol group were undetectable at $240 \mathrm{~min}$; after $30 \mathrm{~min}$ they increased to $8.2 \pm 1.3$ $\mathrm{mM}$ and reached a peak of $16.5 \pm 1.3 \mathrm{mM}$ at $420 \mathrm{~min}$ (Fig. 1). The plasma concentrations of glucose and insulin were increased $(P<0.001)$ by the meal absorption and were not different between the two groups (Fig. 1).

Plasma concentrations of leucine, isoleucine, and KIC. During the post-absorptive period (0-240 $\mathrm{min})$, the plasma concentrations of leucine, isoleucine, and KIC were not different between the water and ethanol groups. Meal administration increased $(P<0.001)$ the plasma concentrations of leucine and isoleucine in both groups (Fig. 2). The mean leucine and isoleucine plasma concentrations were greater in the ethanol group $(P$ $<0.02)$. During meal absorption, the plasma KIC concentration increased in the ethanol and decreased in the water group ( $P$ $<0.01$ ). In each study the plasma concentrations of leucine and KIC were nearly at steady state over the last hour of the post-absorptive (180-240 $\mathrm{min}$ ) and absorptive (420-480 $\mathrm{min}$ ) periods.

Leucine kinetics. The infusion rate of radioactive leucine was $7.40 \pm 0.42$ and $7.25 \pm 0.34 \cdot 10^{3} \mathrm{dpm} \cdot \mathrm{kg}^{-1} \cdot \mathrm{min}^{-1}$ during the water and the ethanol studies, respectively. In each study ${ }^{14} \mathrm{CO}_{2},\left[{ }^{14} \mathrm{C}\right] \mathrm{KIC}$, and leucine SA were nearly at steady state over the last hour of the post-absorptive (180-240 $\mathrm{min}$ ) and absorptive (420-480 $\mathrm{min}$ ) periods (Fig. 2). The rate of leucine transmembrane exchange between the intra- and extracellular compartments was not affected by ethanol (water 6.19 \pm 0.90 , ethanol $5.62 \pm 0.50 \mu \mathrm{mol} \cdot \mathrm{kg}^{-1} \cdot \mathrm{min}^{-1}, P=\mathrm{NS}$ ). During the post-absorptive period, leucine rates of appearance (water $2.48 \pm 0.09$, ethanol $2.45 \pm 0.10 \mu \mathrm{mol} \cdot \mathrm{kg}^{-1} \cdot \min ^{-1}$ ), oxidative disposal (water $0.37 \pm 0.06$, ethanol $0.37 \pm 0.07 \mu \mathrm{mol} \cdot \mathrm{kg}^{-1}$. $\min ^{-1}$ ), and non-oxidative disposal (water $2.11 \pm 0.09$, ethanol $2.09 \pm 0.08 \mu \mathrm{mol} \cdot \mathrm{kg}^{-1} \cdot \mathrm{min}^{-1}$ ) were not different between the two groups (Fig. 3). Meal administration decreased ( $P$ $<0.001$ ) by $\sim 30 \%$ the rate of endogenous leucine appearance (water $1.76 \pm 0.15$, ethanol $1.62 \pm 0.10 \mu \mathrm{mol} \cdot \mathrm{kg}^{-1} \cdot \mathrm{min}^{-1}$ ), increased $(P<0.01)$ by $\sim 10 \%$ the rate of nonoxidative leucine disappearance (water 2.33 \pm 0.16 , ethanol 2.38 $\pm 0.09 \mu \mathrm{mol} \cdot$ $\mathrm{kg}^{-1} \cdot \mathrm{min}^{-1}$ ) and resulted in a positive net leucine balance (water $0.55 \pm 0.09$, ethanol $0.74 \pm 0.06 \mu \mathrm{mol} \cdot \mathrm{kg}^{-1} \cdot \mathrm{min}^{-1}$ ), without significant differences between the water and the ethanol groups. The rate of leucine oxidation was increased $(P<0.001)$ by meal infusion in both groups; however, when compared with water $\left(0.67 \pm 0.08 \mu \mathrm{mol} \cdot \mathrm{kg}^{-1} \cdot \mathrm{min}^{-1}\right)$, wine administration blunted the increase in leucine oxidation rate $(0.51 \pm 0.04$ $\left.\mu \mathrm{mol} \cdot \mathrm{kg}^{-1} \cdot \min ^{-1}\right)$ by $24 \%(P<0.03)$.

Concentrations and FSR of plasma proteins. The plasma concentrations of albumin, fibrinogen, and IgG were not different between the ethanol and water group and were not affected by meal administration (data not shown). The SA of leucine derived from the hydrolysis of VLDL-apo-B100, determined in three subjects of the water and of the ethanol group, reached a plateau after $5 \mathrm{~h}$, matching the plasma KIC SA used to calculate the plasma protein FSR during the absorptive state (Fig. 4).

The SA of leucine derived from hydrolyzed albumin, fibrinogen, and IgG increased linearly $(P<0.001)$ from 180 to $240 \mathrm{~min}$ and from 420 to $480 \mathrm{~min}$ (Table I and Fig. 5). A straight line fit was adequate to describe the time course of label incorporation for the data from each subject during both studies. During the post-absorptive period, the estimated daily FSRs of albumin (water $8.6 \pm 0.5$, ethanol $10.2 \pm 0.8 \%$ ), fibrinogen (water $28.3 \pm 3.0$, ethanol $26.8 \pm 1.7 \%$ ), and IgG (water $4.9 \pm 0.5$, ethanol $4.5 \pm 0.3 \%$ ) were not significantly different between the two groups. In the absorptive state, wine ingestion, when compared with water, resulted in a decrease of $\sim 30 \%$ in albumin $(P<0.001)$ and fibrinogen FSR $(P<0.01)$, whereas it did not affect IgG FSR. Meal administration in the water group, when compared with the previous post-absorptive period, increased albumin FSR by $35 \%\left(11.6 \pm 1.0 \% \cdot \mathrm{d}^{-1}, P<0.01\right)$, IgG FSR by $33 \%\left(6.5 \pm 0.8 \% \cdot \mathrm{d}^{-1}, P<0.01\right)$, and did not significantly affect fibrinogen FSR $\left(32.6 \pm 3.8 \% \cdot \mathrm{d}^{-1}, P\right.$ $=0.08$ ). Meal administration in the wine group, when compared with the previous post-absorptive period, decreased the FSR of albumin by $23 \%(7.9 \pm 0.6 \%, P<0.02)$, the FSR of fibrinogen by $14 \%(23.0 \pm 1.4 \%, P<0.01)$, and increased the FSR of IgG by $29 \%(5.8 \pm 0.5 \%, P<0.05)$. When the FSR of IgG were calculated using plasma leucine $S A$ as precursor pool for protein synthesis, similar statistical results were obtained (data not shown).

\section{Discussion}

These data indicate that, compared with water, the ingestion of a bottle of table wine during a meal decreases the rate of leucine oxidation and does not affect the estimates of whole body protein breakdown and synthesis and the FSR of IgG, whereas it markedly reduces the FSR of hepatic proteins (albumin and fibrinogen).

The suppressive effect of wine ingestion on the rate of leucine oxidation is in agreement with the data of Shelmet et al. (5). These authors originally reported that, during a combined glucose plus ethanol infusion, ethanol was used as preferred 


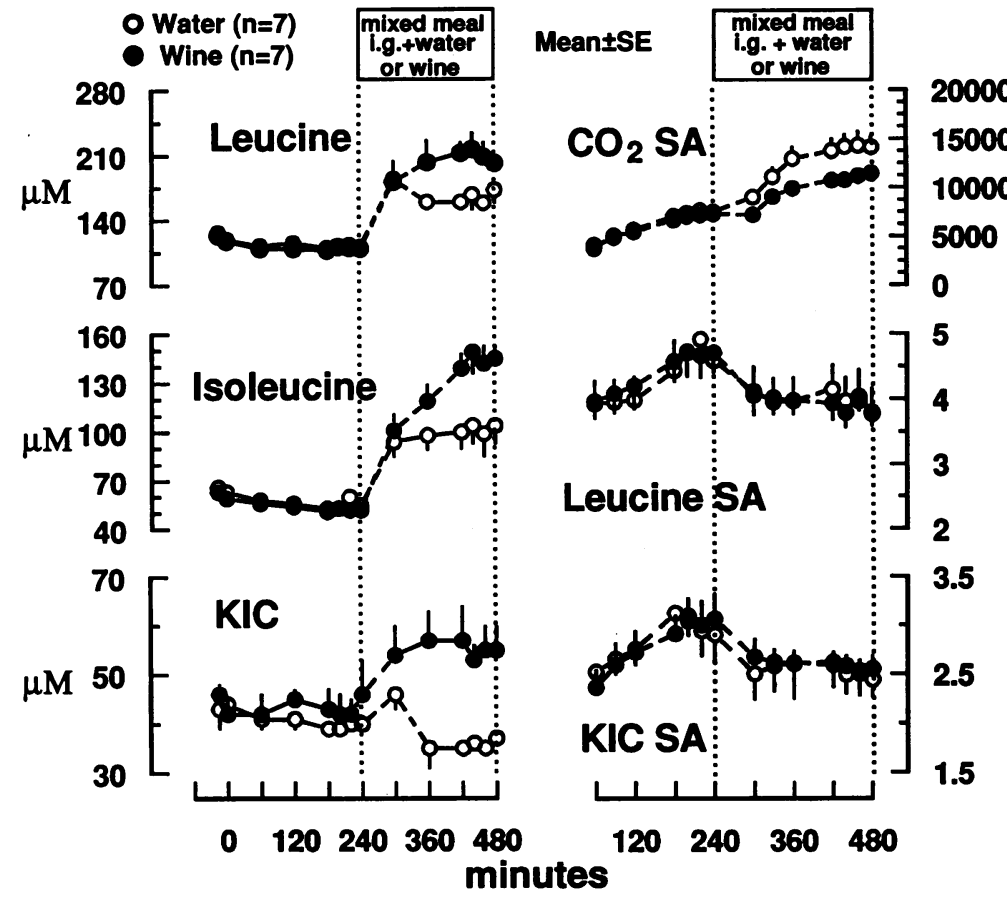

20000

15000

$10000 \mathrm{dpm} / \mathrm{nmol}$

5000

dpm/nmol

Figure 2. Plasma concentrations of leucine, isoleucine, and $\mathrm{KIC}$, SA of expired $\mathrm{CO}_{2}$, and plasma SA of leucine and $\mathrm{KIC}$ in two groups of healthy volunteers (water, empty circles; wine,

$\mathrm{dpm} / \mathrm{nmol}$ filled circles) during the post-absorptive (0-240 $\mathrm{min}$ ) and absorptive (240$480 \mathrm{~min}$ ) periods. In the absorptive state the plasma leucine, isoleucine, and KIC concentrations were significantly greater $(P<0.05)$ during wine ingestion. fuel, decreasing protein oxidation by $39 \%$ (urinary nitrogen excretion) and to a larger extent glucose and lipid oxidation (indirect calorimetry). It is likely that since our volunteers were not chronic alcoholics, most of ethanol oxidation was performed in the liver by alcohol dehydrogenase (10). However, the degree of reduction in leucine oxidation (24\%) indicates that the substrate competition for oxidation took place not only in the liver but occurred also in extrahepatic tissues. In the liver, alcohol dehydrogenase converts ethanol to acetaldehyde, which is subsequently oxidized to acetate (10). In contrast to acetate, acetaldehyde, at the plasma ethanol concentrations obtained in this study, does not reach the systemic circulation because it is completely oxidized in the hepatocytes (5). Consequently, acetate must be the primary ethanol substrate responsible in extrahepatic tissues for the reduced oxidation of amino acids and other fuels (5). It should be pointed out that in both this and the Shelmet study the suppressive effect of ethanol on protein oxidation ( 39 and $24 \%$, respectively) might have been overesti-

\section{LEUCINE KINETICS}
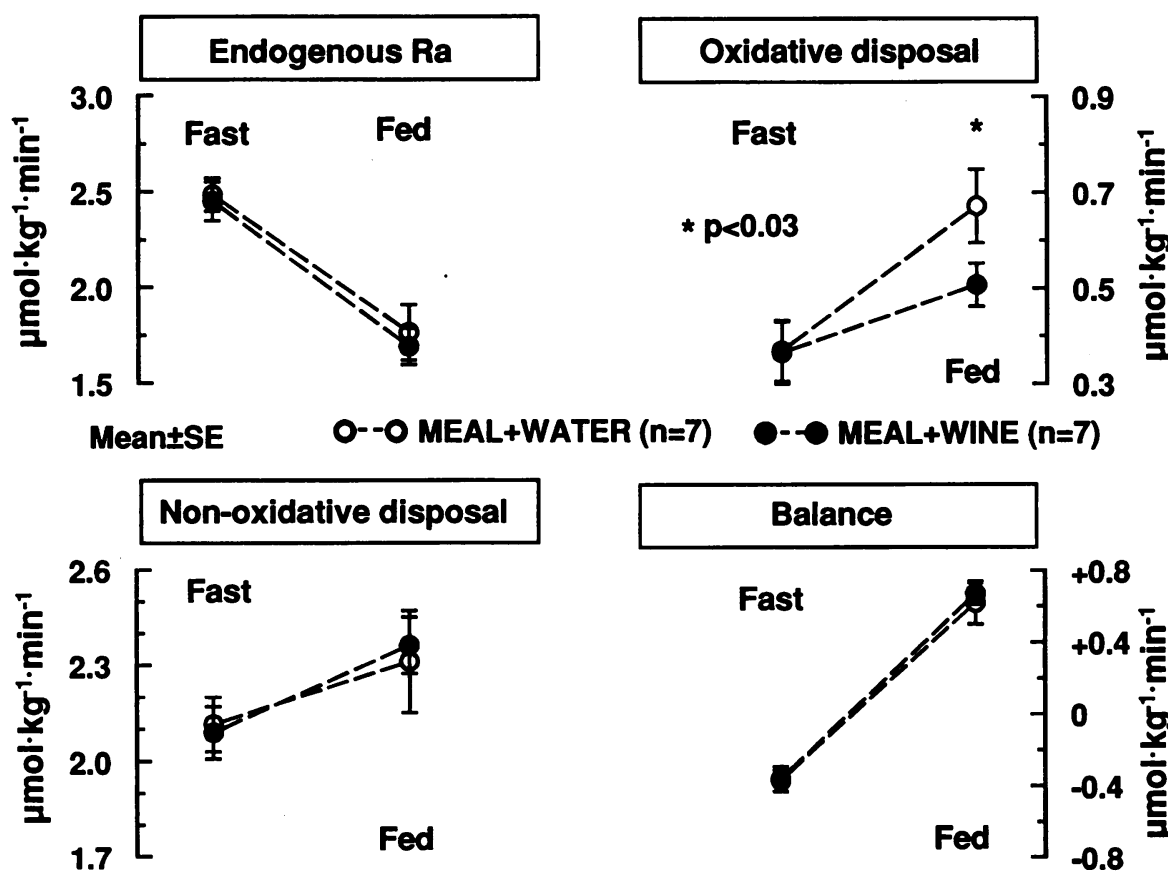

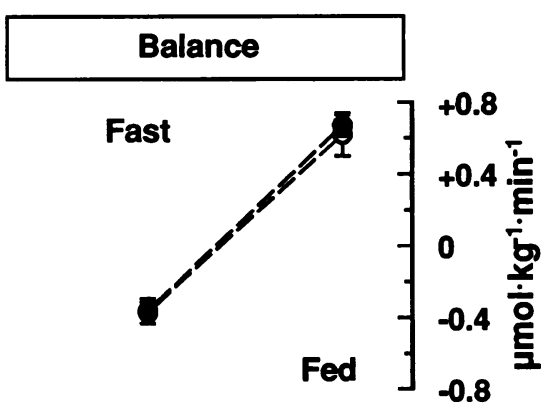

Figure 3. Rates of endogenous appearance $(R a)$, oxidative, nonoxidative disposal, and of net balance of leucine in two groups of healthy volunteers (water, empty circles; wine, filled circles) during the post-absorptive (0-240 $\mathrm{min}$ ) and absorptive (240-480 $\mathrm{min}$ ) periods. When compared with the postabsorptive period (Fast), meal absorption $(F e d)$ significantly $(P<0.01)$ decreased leucine $\mathrm{Ra}$ and increased the rates of oxidative and nonoxidative leucine disposal and of leucine balance in the subjects of both groups. When compared with meal plus water, meal plus wine resulted in a blunted increase $(P=0.0231)$ in the rate of leucine oxidation. 

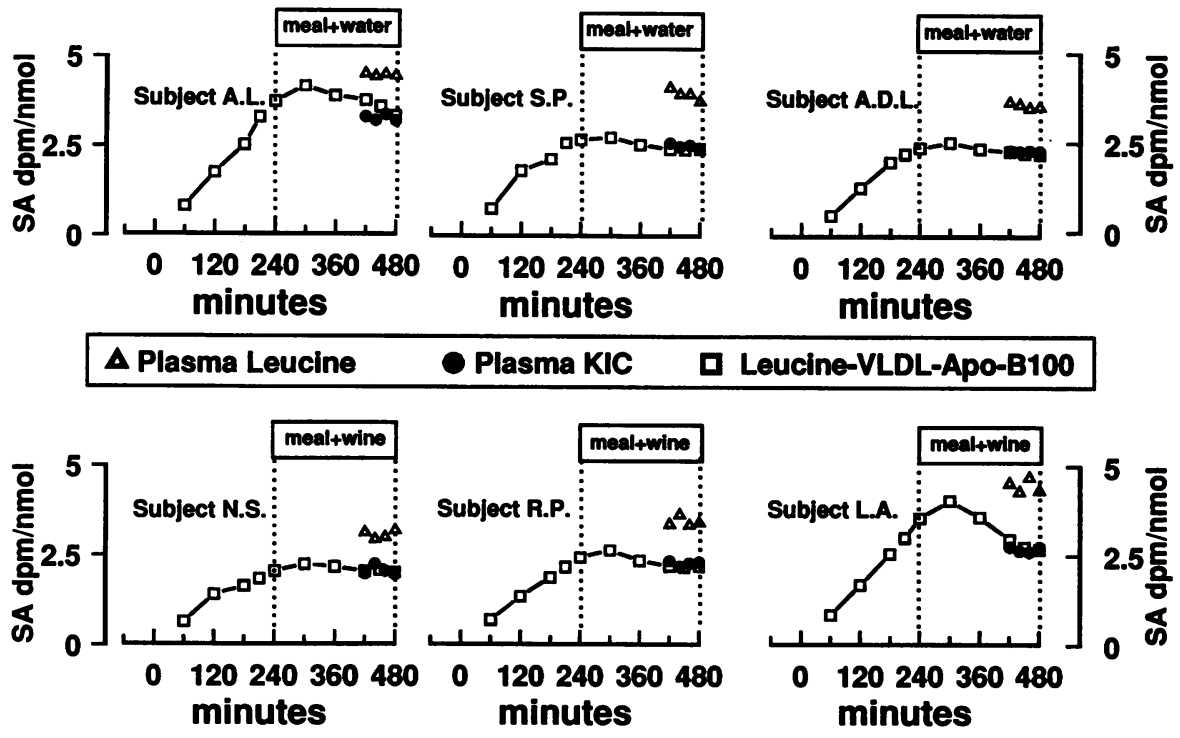

Figure 4. SA of plasma leucine, KIC, and of leucine derived from the hydrolysis of the hepatic protein VLDL-apo-B100 in three subjects of the water (empty circles) and of the ethanol (filled circles) group. After starting a constant infusion of $\left[1-{ }^{14} \mathrm{C}\right]$ leucine at $0 \mathrm{~min}$, the SA of leucine-VLDL-apo-B100 progressively increased to reach the plateau after $5 \mathrm{~h}$, i.e., the time required to completely replace the pool of circulating VLDL-apoB100. Since under this condition the SA of leucine-VLDL-apo-B100 equals the SA of its leucyl-tRNA, it can be used to determine the SA of the intrahepatic precursor pool of protein synthesis. During the absorptive period, the SA of plasma KIC at steady state (420-480 $\mathrm{min}$ ) was very close to the SA of leucine-VLDL-apo-B100 in all subjects, whereas the SA of plasma leucine overestimated it by $\sim 30-40 \%$.

mated. In both studies ethanol was added, not isocalorically substituted, to the other nutrients; therefore, it remains to be established if the greater caloric content of the meal alone contributed to the reduction of the oxidative rates.

To minimize the potential methodological errors deriving from an inappropriate use of Waterlow's equation (27), the rates of leucine kinetics were calculated only over the last hour of the post-absorptive and absorptive period, i.e., when the plasma concentrations and SA of leucine and KIC reached an apparent steady state. Over this time period, the plasma concentrations of leucine and KIC were significantly higher in the ethanol group due to a previous progressive rise which started $\sim 1 \mathrm{~h}$ after the enteral infusion of the mixed meal and continued until $420 \mathrm{~min}$ (Fig. 2). Theoretically, ethanol ingestion caused the increase in plasma leucine concentration by either increasing the rate of leucine appearance or decreasing the rates of trans- membrane leucine transport or of intracellular leucine disposal. The last hypothesis appears to be the most likely because: $(a)$ acute ethanol ingestion does not interfere with the enteral absorption of amino acids (7); $(b)$ over the steady state period the rate of endogenous leucine appearance was not different between the ethanol and the water studies; $(c)$ ethanol has no effect on the L transport system $(33,34) ;(d)$ the rates of leucine transmembrane exchange between the intra- and the extracellular compartments were similar between the two groups; and ( $e$ ) over the steady state period the rate of oxidative leucine disposal was significantly decreased by ethanol ingestion. Thus, it is probable that the preferential oxidation of ethanol and its metabolites resulted in an expansion of the intraand extracellular pools of leucine and other amino acids. In this regard, it is interesting to underline the result of the increased plasma KIC concentration during the absorptive state of the

Table I. Increase in the SA of Leucine Derived from Hydrolyzed Albumin, Fibrinogen, and Immunoglobulins (IgG), Plasma KIC SA, and FSR of the Plasma Proteins in Two Groups of Healthy Volunteers over the Last Hour of the Post-absorptive and Absorptive Periods

\begin{tabular}{|c|c|c|c|c|c|c|}
\hline & \multicolumn{6}{|c|}{ Post-absorptive state } \\
\hline & \multicolumn{2}{|c|}{ Albumin } & \multicolumn{2}{|c|}{ Fibrinogen } & \multicolumn{2}{|c|}{ Immunoglobulins } \\
\hline & Water & Ethanol & Water & Ethanol & Water & Ethanol \\
\hline SA increase $\left(10^{-3} \mathrm{dpm} \cdot \mathrm{nmol}^{-1} \cdot \mathrm{min}^{-1}\right)$ & $0.177 \pm 0.015$ & $0.210 \pm 0.019$ & $0.585 \pm 0.045$ & $0.550 \pm 0.043$ & $0.101 \pm 0.009$ & $0.922 \pm 0.008$ \\
\hline Plasma KIC SA $(d p m / n m o l)$ & $2.98 \pm 0.20$ & $2.96 \pm 0.23$ & $2.98 \pm 0.20$ & $2.96 \pm 0.23$ & $2.98 \pm 0.20$ & $2.96 \pm 0.23$ \\
\hline \multirow[t]{4}{*}{ FSR $\left(\% \cdot d^{-1}\right)$} & $8.6 \pm 0.5$ & $10.2 \pm 0.8$ & $28.3 \pm 3$ & $26.8 \pm 1.7$ & $4.9 \pm 0.5$ & $4.5 \pm 0.3$ \\
\hline & \multicolumn{6}{|c|}{ Absorptive state } \\
\hline & \multicolumn{2}{|c|}{ Albumin } & \multicolumn{2}{|c|}{ Fibrinogen } & \multicolumn{2}{|c|}{ Immunoglobulins } \\
\hline & Water & Ethanol & Water & Ethanol & Water & Ethanol \\
\hline SA increase $\left(10^{-3} \mathrm{dpm} \cdot \mathrm{nmol}^{-1} \cdot \mathrm{min}^{-1}\right)$ & $0.199 \pm 0.016$ & $0.139 \pm 0.010$ & $0.559 \pm 0.063$ & $0.402 \pm 0.036$ & $0.111 \pm 0.009$ & $0.102 \pm 0.008$ \\
\hline Plasma KIC SA $(d p m / n m o l)$ & $2.47 \pm 0.17$ & $2.52 \pm 0.15$ & $2.47 \pm 0.17$ & $2.52 \pm 0.15$ & $2.47 \pm 0.17$ & $2.52 \pm 0.15$ \\
\hline $\operatorname{FSR}\left(\% \cdot d^{-1}\right)$ & $11.6 \pm 1.0$ & $7.9 \pm 0.6$ & $32.6 \pm 3.8$ & $23.0 \pm 1.4$ & $6.5 \pm 0.8$ & $5.8 \pm 0.5$ \\
\hline
\end{tabular}

In the post-absorptive state the plasma protein FSR were not different between the control (water) and the ethanol group. Meal plus water administration increased $(P<0.01)$ albumin and IgG FSR, whereas meal plus wine administration increased $(P<0.05)$ only IgG FSR and decreased $(P<0.02)$ below the post-absorptive values the FSR of the hepatic proteins albumin and fibrinogen. 


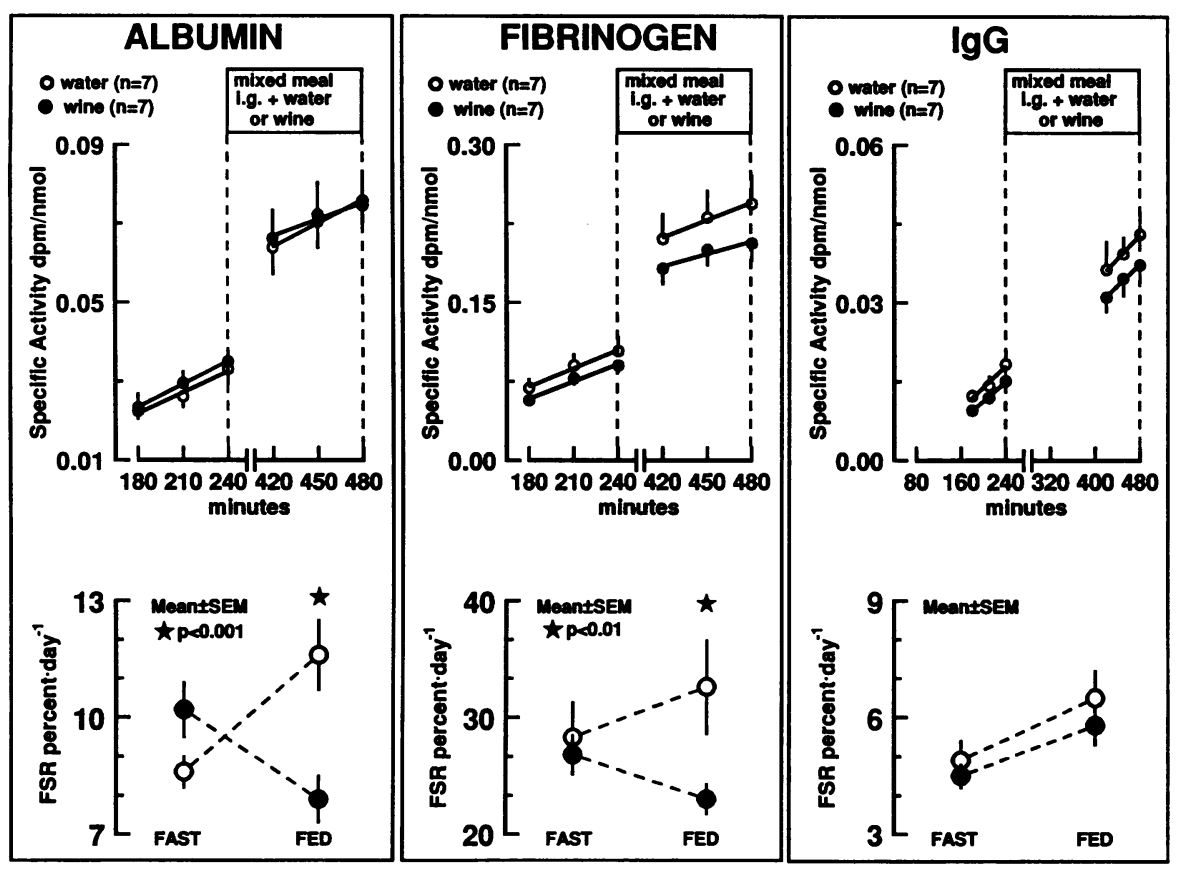

Figure 5. Plasma KIC SA, SA of leucine derived from hydrolyzed albumin, fibrinogen, and immunoglobulins (IgG), and FSR of the plasma proteins in two groups of healthy volunteers (water, empty circles; wine, filled circles) during the post-absorptive (FAST, 0-240 $\mathrm{min}$ ) and absorptive (FED, 240-480 min) periods. In the postabsorptive state the plasma protein FSRs were not different between the control (water) and the ethanol group. In the absorptive state, wine ingestion, when compared with water, resulted in an $\sim 30 \%$ decrease in albu$\min (P<0.001)$ and fibrinogen FSR $(P$ $<0.01$ ), whereas it did not affect IgG FSR. ethanol study in contrast with the reduced concentration of the control study. This exquisite sensitivity of plasma KIC to the changes in the rates of leucine oxidation can be explained by the strategic position of KIC in the chain of intracellular leucine catabolism, immediately preceding the irreversible oxidative reaction.

A question that the data of this study cannot address regards the subsequent fate of the amino acids temporarily saved by ethanol oxidation. A previous study, also performed by giving ethanol with meals to nonalcoholic healthy volunteers, reported an increased urinary nitrogen excretion in the following overnight hours (35), suggesting that these amino acids are subsequently lost through oxidation. However, the habitual consumption of ethanol would lead to a steady expansion of the free amino acid pool according to studies in alcoholic humans (36, $37)$ or chronically ethanol fed rats $(38,39)$, showing increased concentrations of branched chain amino acids in plasma (36$39)$ and tissues $(38,39)$.

The most significant result of this study regards the substantial reduction in the FSR of albumin and fibrinogen observed in the ethanol group. Theoretically, since the water and ethanol studies differed for two variables, i.e., the ingestion of wine and the resultant greater caloric content of the meal, the inhibitory effect on the FSR of the two hepatic proteins could be due to one or both of these variables. However, it is more reasonable to hypothesize that a greater energy intake should increase, not decrease, the synthesis of hepatic proteins; thus if this variable played any role it resulted in an underestimate of the inhibitory effect of ethanol on hepatic protein metabolism. Despite the fact that estimates of whole body protein synthesis were not significantly affected by ethanol, the FSR of the two most represented plasma proteins synthesized by the liver was reduced by $\sim 30 \%$. Assuming that from the rates of nonoxidative leucine disposal it is possible to accurately calculate the mean rates of whole body protein synthesis $(40,41)$, this result could be explained either by the fact that a $30 \%$ reduction in hepatic protein synthesis might not significantly change the estimates of whole body protein synthesis, due to the limited contribution $(\sim 10 \%)$ of liver to whole body protein metabolism (42), or by the fact that ethanol impaired the secretion rather than the synthesis of albumin and fibrinogen. Both hypotheses might be valid if the results of previous studies performed in vitro or in vivo in rats can be extrapolated to humans. The addition of ethanol to various in vitro preparations, such as perfused livers or isolated hepatocytes (for review see reference 10), inhibits protein synthesis, whereas acute ethanol administration to rats impairs both the synthesis $(4,43)$ and the secretion $(43,44)$ of hepatic proteins. The mechanism(s) by which acute ethanol administration impairs hepatic protein metabolism remains to be established. The fact that ethanol is almost exclusively metabolized by the liver (10) and that wine administration selectively decreased the FSR of hepatic proteins (albumin, fibrinogen), not those of extrahepatic proteins ( $\mathrm{IgG}$, estimates of whole body protein synthesis), indicates that the adverse effect of ethanol on protein metabolism must be a direct consequence of its oxidation. Ethanol oxidation might interfere with protein synthesis and/or secretion through the production of toxic catabolite(s) and/or changes in the redox state.

The results of the control study confirm previous data (45) demonstrating that nutrient absorption leads to protein anabolism (positive rates of net leucine balance) by decreasing the estimates of protein breakdown (by $\sim 30 \%$ ) and increasing those of protein synthesis (by $\sim 10 \%$ ). The increase in protein synthesis was not shared by all body proteins. Among the plasma proteins, the FSR of albumin and IgG increased by $\sim 35 \%$, whereas that of fibrinogen was unaffected. Experimental evidence suggests that post-prandial hyperinsulinemia may be responsible for this differential effect $(20,46,47)$. The action of insulin on individual protein synthetic rates should be due to a direct effect on the rates of transcription of the specific mRNAs, as demonstrated in cultured rat hepatocytes (48).

To our knowledge, this is the first time that the intravascular synthetic rates of human IgG were determined in vivo. The daily FSR obtained in the post-absorptive state of $\sim 5 \%$ is 
comparable with the daily fractional catabolic rate of $\sim 6 \%$, calculated using radioiodinated human IgG (49). The marked increase in IgG FSR during meal absorption proves that strict links exist between nutrition and the immune system. This might explain the reduced serum IgG concentrations $(50,51)$ and responses to infectious agents (52), reported in experimental (51) or clinical $(50,52)$ protein malnutrition. The post-prandial increase in albumin and IgG synthesis may represent an additional physiologic mechanism useful to the economy of whole body protein. In contrast with glucose and lipids, the ingested essential amino acids cannot be stored to be used in the postabsorptive state and, if not incorporated into newly synthesized proteins, are irreversibly lost through oxidation (53-56). From the data of the present study, we can estimate that the postprandial increase in albumin and IgG synthesis resulted in the net incorporation of $>2 \mathrm{~g}$ of amino acids, an amount equivalent to $\sim 8 \%$ of the enterally delivered amino acids. Thus, the postprandial increase in the synthesis of albumin (57), IgG, and potentially of other plasma proteins may function as a temporary storage system for ingested amino acids, which can be later used for local protein synthesis in all tissues where the plasma proteins undergo degradation. This concept is in agreement with the data reported in dogs suggesting that hepatic secreted plasma proteins may serve as an important source of amino acids in peripheral tissues $(58,59)$. In conclusion, the ingestion during a meal of $70 \mathrm{~g}$ of ethanol, an amount usual for many social drinkers, selectively impairs the hepatic protein metabolism. The clinical history of chronic alcoholics includes the progressive development of liver injury (10) and hypoalbuminemia (60), usually attributed to protein malnutrition (9). However, alcoholics can develop liver cirrhosis despite a daily dietary protein intake of $100 \mathrm{~g}$ or more (10). The data of the present study suggest that the repeated ingestion of $70 \mathrm{~g}$ or more of ethanol during meals might: $(a)$ directly lead to liver injury by reducing hepatic protein synthesis and/or inducing the intracellular accumulation of secretory proteins; and $(b)$ cause the hypoalbuminemia observed in chronic alcoholics $(60)$, by preventing the post-prandial increase in albumin FSR. Therefore, in the actual debate (61) on the potential benefits of alcohol on lipid (62) and glucose (63) metabolism the effects on hepatic protein metabolism must be considered. In this regard, doseresponse studies on the effects of ethanol on hepatic protein metabolism are required to detect the threshold for the harmful effect. In particular, it would be interesting to establish if the amounts of ethanol demonstrated to decrease the risk of myocardial infarction (25-40 g/d) (62) adversely affect hepatic protein metabolism similarly to the larger dose used in the present study.

\section{Acknowledgments}

The authors are indebted to Mrs. Vania Cesarini for skillful technical assistance.

This study was supported by research grants 94024112.CTO4 and 93.00352.PF40 from CNR (Comitato Nazionale delle Ricerche), Italy.

\section{References}

1. Mitchell, M. C., and H. F. Herlong. 1986. Alcohol and nutrition: caloric value, bioenergetics, and relationship to liver damage. Annu. Rev. Nutr. 6:457474.

2. Mørland, J., A. Bessesen, and L. Svendsen. 1979. Incorporation of labelled amino acids into proteins of isolated parenchymal and nonparenchymal rat liver cells in the absence and presence of ethanol. Biochim. Biophys. Acta. 561:464474.

3. Rothschild, M. A., M. Oratz, and S. S. Schreiber. 1974. Alcohol, amino acids, and albumin synthesis. Gastroenterology. 67:1200-1213.

4. Jeejeebhoy, K. N., M. J. Phillips, A. Bruce-Robertson, J. Ho, and U. Sodtke 1972. The acute effect of ethanol on albumin, fibrinogen and transferrin synthesis in the rat. Biochem. J. 126:1111-1126.

5. Shelmet, J. J., G. A. Reichard, C. L. Skutches, R. D. Hoeldtke, O. E. Owen, and G. Boden. 1988. Ethanol causes acute inhibition of carbohydrate, fat, and protein oxidation and insulin resistance. J. Clin. Invest. 81:1137-1145.

6. Mc Donald, J. T., and S. Margen. 1986. Wine versus ethanol in human nutrition. I. Nitrogen and calorie balance. Am. J. Clin. Nutr. 29:1093-1103.

7. Bunout, D., M. Petermann, G. Ugarte, G. Barrera, and H. Iturriaga. 1987. Nitrogen economy in alcoholic patients without liver disease. Metab. Clin. Exp. 36:651-653.

8. Reinus, J. F., S. B. Heymsfield, R. Wiskind, K. Casper, and J. T. Galambos. 1989. Ethanol: relative fuel value and metabolic effects in vivo. Metab. Clin. Exp. 38:125-135.

9. Korsten, M. A., and C. S. Lieber. 1979. Nutrition in the alcoholic. Med. Clin. North Am. 63:963-972.

10. Lieber, C. S. 1980. Alcohol, protein metabolism, and liver injury. Gastroenterology. 79:373-390.

11. Schwenk, W. F., B. Beaufrere, and M. W. Haymond. 1985. Use of reciprocal pool specific activities to model leucine metabolism in humans. Am. J. Physiol. 249:E646-E650.

12. McGuire, E., J. Helderman, J. Tobin, R. Andres, and M. Berman. 1976. Effects of arterial venous sampling on analysis of glucose kinetics in man. $J$. Appl. Physiol. 41:565-573.

13. De Feo, P., and M. W. Haymond. 1991. Effects of substrates on protein metabolism in humans. In Protein Metabolism in Diabetes Mellitus. K. S. Nair, editor. University of Vermont, Burlington. 199-206.

14. Herbert, V., K. Lau, C. Gottlieb, and S. Bleicher. 1965. Coated charcoal immunoassay of insulin. J. Clin. Endocrinol. \& Metab. 25:1375-1384.

15. Lundquist, F. 1957. The determination of ethyl alcohol in blood and tissues. In Methods of Biochemical Analysis, Vol VII. D. Glick, editor. Interscience, New York. 217-251.

16. Doumas, B. T., W. Watson, and H. G. Biggs. 1971. Albumin standards and the measurement of serum albumin with bromcresol green. Clin. Chim. Acta. 31:87-96.

17. Jacobsoon, K. 1955. Studies on determination of fibrinogen in human blood plasma. Scand. J. Clin. Lab. Invest. 7:14-19.

18. Whicher, J. T., C. Warren, and R. E. Chambers. 1984. Immunochemical assays for immunoglobulins. Ann. Clin. Biochem. 21:78-91.

19. Horber, F. F., J. Kahl, L. Lecavalier, B. Krom, and M. W. Haymond. 1989. Determination of leucine and $\alpha$-ketoisocaproic acid concentrations and specific activity in plasma and leucine specific activities in proteins using highperformance liquid chromatography. J. Chromatogr. 495:81-94.

20. De Feo, P., E. Volpi, P. Lucidi, G. Cruciani, G. Reboldi, D. Siepi, E. Mannarino, F. Santeusanio, P. Brunetti, and G. B. Bolli. 1993. Physiological increments in plasma insulin concentrations have selective and different effects on synthesis of hepatic proteins in normal humans. Diabetes. 42:995-1002.

21. Cox, A. M., R. Turner, and E. H. Cooper. 1987. Separation and characterization of glycoproteins from normal, pregnancy, and acute inflammatory sera. $J$. Chromatogr. 397:213-222.

22. Manil, L., P. Motte, P. Pernas, F. Troalen, C. Bohuon, and D. Bellat. 1986. Evaluation of protocols for purification of mouse monoclonal antibodies. J. Immunol. Methods. 90:25-37.

23. Havel, R. J., H. A. Eder, and J. H. Bragdon. 1955. The distribution and chemical composition of ultracentrifugally separated lipoproteins in human serum. J. Clin. Invest. 34:1345-1353.

24. Hoerr, R. A., D. E. Matthews, D. M. Bier, and V. R. Young. 1991. Leucine kinetics from $\left[{ }^{2} \mathrm{H}_{3}\right]-$ and $\left[{ }^{13} \mathrm{C}\right]$ leucine infused simultaneously by gut and vein. Am. J. Physiol. 260:E111-E117.

25. Hoerr, R. A., Y. M. Yu, D. A. Wagner, J. F. Burke, and V. R. Young. 1989. Recovery of ${ }^{13} \mathrm{C}$ in breath from $\mathrm{NaH}^{13} \mathrm{CO}_{3}$ infused by gut and vein: effect of feeding. Am. J. Physiol. 257:E426-E438.

26. Matthews, D. E. 1993. Stable isotope methodologies in studying human amino acid and protein metabolism. Ital. J. Gastroenterol. 25:72-78.

27. De Feo, P., and M. W. Haymond. 1994. Principles and calculations of the labelled leucine methodology to estimate protein kinetics in humans. Diabetes, Nutrition and Metabolism. 7:165-184.

28. Ginsberg, H. N. 1990. Lipoprotein physiology and its relationship to atherogenesis. Endocrinol. Metab. Clin. North Am. 19:211-228.

29. Venkatesan, S., P. J. Pacy, D. Wenham, and D. Halliday. 1990. Verylow-density lipoprotein-apolipoprotein B turnover studies in normal subjects: a stable isotope study. Biochem. Soc. Trans. 18:1192-1193.

30. Arends, J., R. E. Ostlund, and D. M. Bier. 1991. Measurement of in-vivo protein synthesis using stable isotopes: comparison of four different amino acid 
tracers. In Protein Metabolism in Diabetes Mellitus. K. S. Nair, editor. University of Vermont, Burlington. 274a. (Abstr.)

31. Winer, B. J. 1972. Statistical Principles in Experimental Design. 2nd edition. McGraw-Hill Inc., New York. 261-308.

32. Snedecor, G. W., and W. G. Cochran. 1980. Statistical Methods. 7th edition. The Iowa State University Press, Ames. 149-193, 393-413.

33. Dorio, R. J., J. B. Hoeck, and E. Rubin. 1984. Ethanol treatment selectively decreases neutral amino acid transport in cultured hepatocytes. J. Biol. Chem. 259:11430-11435.

34. Moseley, R. H., and S. M. Murphy. 1989. Effects of ethanol on amino acid transport in basolateral liver plasma membrane vesicles. Am. J. Physiol. 256:G458-G465.

35. Suter, P. M., Y. Schutz, and E. Jequier. 1992. The effect of ethanol on fat storage in healthy subjects. N. Engl. J. Med. 326:983-987.

36. Shaw, S., and C. S. Lieber. 1978. Plasma amino acids abnormalities in the alcoholic: respective role of alcohol, nutrition and liver injury. Gastroenterology. 74:677-683.

37. Avogaro, A., M. Cibin, T. Croatto, A. Rizzo, L. Galimberti, and A. Tiengo. 1986. Alcohol intake and withdrawal: effects on branched chain amino acids and alanine. Alcoholism (Zagreb). 10:300-304.

38. Stanko, R. T., E. L. Morse, and S. A. Adibi. 1979. Prevention of effects of ethanol on amino acid concentrations in plasma and tissues by hepatic lipotropic factors in rats. Gastroenterology. 76:132-138.

39. Bernal, C. A., J. A. Vazquez, and S. A Adibi. 1993. Leucine metabolism during chronic ethanol consumption. Metab. Clin. Exp. 42:1084-1086.

40. Schwenk, W. F., E. Rubanyi, and M. W. Haymond. 1987. Effect of a protein synthetic inhibitor on in vivo estimates of protein synthesis in dogs. Am. J. Physiol. 252:E595-E598.

41. Nair, K. S., D. Halliday, and R. C. Griggs. 1988. Leucine incorporation into mixed skeletal muscle protein in humans. Am. J. Physiol. 254:E208-E213.

42. Munro, H. N. 1982. Interaction of liver and muscle in the regulation of metabolism in response to nutritional and other factors. In The Liver: Biology and Pathobiology. I. M. Arias, H. Popper, and D. Schachter, editors. Raven Press, New York. 677-691.

43. Sorrell, M. F., J. M. Nauss, T. M. Donohue, and D. J. Tuma. 1983. Effects of chronic ethanol administration on hepatic glycoprotein secretion in the rat. Gastroenterology. 84:580-586.

44. Baraona, E., P. Pikkarainen, M. Salaspuro, F. Finkelman, and C. S. Lieber. 1980. Acute effects of ethanol on hepatic protein synthesis and secretion in the rat. Gastroenterology. 79:104-111.

45. Horber, F. F., and M. W. Haymond. 1990. Human growth hormone prevents the protein catabolic side effects of prednisone in humans. J. Clin. Invest. 86:265-272.

46. De Feo, P., M. Gan Gaisano, and M. W. Haymond. 1991. Differential effects of insulin deficiency on albumin and fibrinogen synthesis in humans. $J$. Clin. Invest. 88:833-840.

47. Lecavalier, L., P. De Feo, and M. W. Haymond. 1991. Isolated hypoisoleu- cinemia impairs whole body but not hepatic protein synthesis in humans. Am. J. Physiol. 261:E578-E586.

48. Hsu, C. J., S. R. Kimball, D. A. Antonetti, and L. S. Jefferson. 1992. Effects of insulin on total RNA, poly (A) ${ }^{+}$RNA, and mRNA in primary cultures of rat hepatocytes. Am. J. Physiol. 263:E1106-E1112.

49. Cohen, S., and T. Freeman. 1960. Metabolic heterogeneity of human gamma-globulin. Biochem. J. 76:475-487.

50. Aref, G. H., M. K. El-Din, A. I. Hassan, and I. I. Araby. 1970. Immunoglobulin in kwashiorkor. J. Trop. Med. Hyg. 73:186-191.

51. Dionigi, R., A. Zonta, L. Dominioni, F. Gnes, and A. Ballabio. 1977. The effects of total parenteral nutrition on immunodepression due to malnutrition. Ann. Surg. 185:467-474.

52. Reddy, V., and S. G. Srikantia. 1964. Antibody response in kwashiorkor. Indian J. Med. Res. 52:1154-1158.

53. Meguid, M. M., D. E. Matthews, D. M. Bier, C. N. Meredith, J. S. Soldner, and V. R. Young. 1986. Leucine kinetics at graded leucine intakes in young men. Am. J. Clin. Nutr. 43:770-780.

54. Meguid, M. M., D. E. Matthews, D. M. Bier, C. N. Meredith, and V. R. Young. 1986. Valine kinetics at graded valine intakes in young men. Am. J. Clin. Nutr. 43:781-786.

55. Meredith, C. N., Z. Wen, D. M. Bier, D. E. Matthews, and V. R Young. 1986. Lysine kinetics at graded lysine intakes in young men. Am. J. Clin. Nutr. 43:787-794.

56. Zhao, X., Z. Wen, C. N. Meredith, D. E. Matthews, D. M. Bier, and V. R. Young. 1986. Threonine kinetics at graded threonine intakes in young men Am. J. Clin. Nutr. 43:795-802.

57. De Feo, P., F. F. Horber, and M. W. Haymond. 1992. Meal stimulation of albumin synthesis: a significant contributor to whole body protein synthesis in humans. Am. J. Physiol. 263:E794-E799.

58. Elwyn, D. H., H. C. Parikh, and W. C. Shoemaker. 1968. Amino acid movements between gut, liver, and periphery in unanesthetized dogs. Am. J. Physiol. 215:1260-1275.

59. Elwyn, D. H. 1970. The role of the liver in regulation of amino acid and protein metabolism. In Mammalian Protein Metabolism. H. N. Munro, editor. Academic Press, New York. 523-557.

60. Lindholm, J., T. Steiniche, E. Rasmussen, G. Thamsborgh, I. O. Nielsen, H. Brockstedt-Rasmussen, T. Storm, L. Hyldstrup, and C. Schou. 1991. Bone disorder in men with chronic alcoholism: a reversible disease? J. Clin. Endocrinol. \& Metab. 73:118-124.

61. Friedman, G. D., and A. L. Klatsky. 1993. Is alcohol good for your health? N. Engl. J. Med. 326:1882-1883.

62. Gaziano, M. J., J. E. Buring, J. L. Breslow, S. Z. Goldhaber, B. Rosner, M. VanDerburgh, W. Willet, and C. H. Hennekens. 1993. Moderate alcohol intake, increased levels of high-density lipoprotein and its subfractions, and decreased risk of myocardial infarction. N. Engl. J. Med. 329:1829-1834.

63. Facchini, F., I. Y.-D. Chen, and G. M. Reaven. 1994. Light-to-moderate alcohol intake is associated with enhanced insulin sensitivity. Diabetes Care. 17:115-119. 